\title{
VOLUME AND PROTEIN CONCENTRATION OF RABBIT UTERINE FLUID
}

\author{
A. G. KULANGARA \\ Department of Anatomy, The Medical College of Pennsylvania, \\ Philadelphia, Pennsylvania
}

(Received 23rd March 1971, accepted 10th May 1971)

\begin{abstract}
Summary. Uterine lumina of rabbits were rinsed in situ with BSA solution. Uterine fluid volume and luminal protein concentration were calculated from radial immunodiffusion and biuret tests of the rinse. The procedure was checked for three sources of error and confirmed by double rinses.

Non-pregnant and lactating rabbits have nearly equal amounts of protein per horn, but different volumes of fluid. With pregnancy, increase of volume occurs without proportionate increase of protein. Peak protein concentrations occur in pregnant and pseudopregnant rabbits at 5 days p.c. Volume and protein concentration of the luminal fluid appear to be sensitive indicators of the hormonal and reproductive status of the uterus.
\end{abstract}

\section{INTRODUCTION}

The presence and accumulation of fluid in the uterine lumen have been noted in several species (Ringler, 1961). In many cases, volume was estimated by aspiration from ligated uteri and ligation produces fluid which is abnormal in many ways (Heap, 1962; Krishnan \& Daniel, 1967). Aspiration without ligation will yield approximate volumes when there is a fair amount of fluid, as in the oestrous rat. However, the non-pregnant rabbit uterus has so little fluid that usually none can be aspirated. Estimation of such small volumes requires a method such as dye dilution and an attempt was made to achieve such an estimation, using Evans blue (Kulangara, 1960).

Various substances in the rabbit uterine lumen have been estimated from rinses (Heap, 1962; Schwick, 1965) or from fluid soaked up with paper (Lutwak-Mann, Boursnell \& Bennett, 1960; Krishnan \& Daniel, 1967; Daniel, 1968). The luminal concentration of these substances remained unknown, however, because no measurements of volume were made.

Hormones influence the composition of uterine fluid (Heap \& Lamming, 1962; Marley \& Robson, 1967). Special proteins and polysaccharides appear in this fluid in early development (Zachariae, 1958; Beier, 1968) and water appears to be exchanged between maternal plasma, blastocyst and uterine fluid (Tuft \& Böving, 1970). Accurate measurements of the volume and concentration are therefore important. A method for the simultaneous deter- 
mination of the volume and protein concentration of rabbit uterine fluid is described here.

\section{MATERIALS AND METHODS}

Dutch belted rabbits, of 1.7 to $2.4 \mathrm{~kg}$ body weight, obtained from a commercial source, were used. The doe was opened midventrally under Diabutal anaesthesia and the vaginal wall was cut longitudinally to expose the cervices. The cervix was mopped free of fluid. The uterotubal junction and the oviduct near it were dissected free of fat and blood vessels. Through a small incision in the oviduct, a polyethylene tube of $0.8 \mathrm{~mm}$ internal diameter was inserted into the anterior end of the uterine horn. About 0.5 to $1 \mathrm{ml}$ of air was introduced through this tube to distend the horn, after which, a known volume of 0.4 $\mathrm{mg} / \mathrm{ml}$ solution of bovine serum albumin (BSA) in $0.9 \% \mathrm{NaCl}$ was injected. The horn was gently stroked to expel the rinse into a tube held to the cervix. When $0 \cdot 1 \mathrm{ml}$ or less of solution was used to rinse the horn, the cervix was kept closed by two fingers, the horn was stroked back and forth to mix the contents and the rinse was recovered through the polyethylene tube in the oviduct.

Any blastocysts in the rinse were removed and the sample centrifuged at $2500 \mathrm{rev} / \mathrm{min}$ for $10 \mathrm{~min}$. The concentration of BSA in the supernatant fluid was determined, in duplicate, by radial immunodiffusion (Fahey \& McKelvey, 1965), using a rabbit antiserum against BSA. The antiserum was free from cross reactions against rabbit albumin and the test detected changes in concentration as small as $0.003 \mathrm{mg} / \mathrm{ml}$. The BSA concentration of the rinse enabled the calculation of uterine fluid volume.

Total protein in the rinse was determined by the biuret test (Gornall, Bardawill \& David, 1949). After subtracting the amount of BSA in the rinse, results could be expressed as mg protein per horn or converted to luminal protein concentration.

Rabbits which readily mated and, when opened, showed corpora lutea but no blastocysts were regarded as pseudopregnant.

\section{RESULTS}

\section{Verification of method}

The rinsing procedure was examined for the following three sources of error.

Contamination by blood and other fluids was minimized by inserting the polyethylene tube through the oviduct adjacent to the uterotubal junction, using very little pressure on the horn and careful cleaning of the cervix and site of entry in the oviduct. These precautions effectively eliminated blood contamination as shown by the total number of red blood cells in the rinse. Red cell counts were less than $10^{5}$, the number present in $0.02 \mu \mathrm{l}$ of blood. Occasional rinses with a red tinge were discarded, but even these had only $5 \times 10^{5}$ red cells, equivalent to $0 \cdot 1 \mu \mathrm{l}$ of blood.

Mixing of rinsing solution and uterine fluid was promoted by the air introduced into the horn, uterine motility and manipulations of the horn. In order to verify whether mixing was complete, a series of horns from non-pregnant 
rabbits were rinsed with different volumes $(0.05$ to $0.6 \mathrm{ml})$ of BSA solution (Table 1). The volume of uterine fluid and amount of protein per horn, calculated from these rinses, are about the same. This indicates complete mixing. It may be pointed out that some of these rinses were recovered through the tube in the oviduct and they gave similar results to the rinses recovered through the cervix. Therefore, cervical secretions do not seem to contribute appreciably to values determined here.

Movement of water and proteins into and out of the uterine lumen during rinsing was checked by the following experiment. Water and $0.45,1.35,1.8$, 2.25 and $2.7 \% \mathrm{NaCl}$ were used to make $0.4 \mathrm{mg} \mathrm{BSA} / \mathrm{ml}$ and $0.6 \mathrm{ml}$ of each solution was used to rinse separate horns of non-pregnant rabbits. The calcu-

TABLE 1

RESULTS OF RINSING NON-PREGNANT RABBIT UTERINE HORNS WITH DIFFERENT VOLUMES OF BSA SOLUTION*

\begin{tabular}{c|c|c|c}
\hline $\begin{array}{c}\text { Volume used } \\
\text { to rinse a } \\
\text { horn }(\mathrm{ml})\end{array}$ & $\begin{array}{c}\text { Protein } \\
\left(\begin{array}{c}\text { mg/ml of } \\
\text { rinse })\end{array}\right.\end{array}$ & $\begin{array}{c}\text { Uterine } \\
\text { fluid) } \\
\text { horn }(\mu \mathrm{l})\end{array}$ & $\begin{array}{c}\text { Total protein/ } \\
\text { horn }(\mathrm{mg})\end{array}$ \\
\hline 0.5 & 5.23 & 15 & 0.319 \\
0.1 & 2.33 & 13 & 0.223 \\
0.1 & 2.42 & 17 & 0.244 \\
0.1 & 3.73 & 11 & 0.374 \\
0.3 & 1.08 & 14 & 0.220 \\
0.3 & 1.39 & 8 & 0.309 \\
0.3 & 1.46 & 11 & 0.333 \\
0.4 & 0.819 & 27 & 0.189 \\
0.4 & 0.840 & 35 & 0.204 \\
0.5 & 0.787 & 33 & 0.210 \\
0.5 & 0.967 & 26 & 0.309 \\
0.6 & 0.850 & 12 & 0.280 \\
\hline Mean $\pm 95 \%$ confidence & $18.5 \pm 5.8$ & $0.268 \pm 0.038$ \\
interval & \multicolumn{4}{l}{} \\
Mean protein concentration of uterine fluid: $14.5 \mathrm{mg} / \mathrm{mI}$. \\
Each line above contains values from a single horn. \\
* Solution of bovine serum albumin (BSA) in $0.9 \% \mathrm{NaCl}$, \\
containing 0.4 mg BSA/ml.
\end{tabular}

lated uterine fluid volumes were $-34,-31,33,49,90$ and $106 \mu 1$, respectively, indicating a loss of water with aqueous and $0.45 \% \mathrm{NaCl}$ solutions and a gain of water with 1.35 to $2.7 \% \mathrm{NaCl}$ solutions. But, in all cases, the amount of protein per horn was the same (mean \pm S.E. was $0.294 \pm 0.030 \mathrm{mg}$ ) suggesting that there is no significant movement of protein during rinsing, even when hypo- or hyperosmotic solutions are used. The procedure seems to be applicable during pregnancy as well, since the freezing point depression of $0.9 \% \mathrm{NaCl}$ is 0.531 (Handbook of Chemistry and Physics, 1968) and that of uterine fluid at 4 to 6 days post coitum (p.c.) is $0.536 \pm 0.005$ (Tuft \& Böving, 1970).

The method was further verified by an experiment in which each horn was rinsed twice. The horn was first rinsed with a known volume $(x)$ of $0.06 \%$ nigrosin, the effluent volume $(\mathrm{v})$ was measured and the horn again rinsed with a known volume of $0.9 \% \mathrm{NaCl}$. Spectrophotometric estimation of dye concen- 
tration in the second rinse gave the volume $(w)$ of fluid left in the horn after collection of the first rinse. Therefore, a second estimate of uterine fluid volume (y) could be obtained from the relation $x+y=v+w$. For six horns tested in this way, $x+y$ and $v+w$ differed by less than $5 \%$ of their mean.

The variability of the entire method is $14 \%$ for $\mathrm{mg}$ protein per horn and $32 \%$ for fluid volume (Table 1), some of which is due to uterine horns that varied in length from 6.5 to $14 \mathrm{~cm}$. The values for volume strongly suggest two distinct states of the uterus, one with a low volume of fluid and high protein concentration and another with about double the volume of fluid of lower protein concentration.

TABLE 2

UTERINE FLUID VOLUME AND PROTEIN CONCENTRATION IN PREGNANT, LAGTATING AND PSEUDOPREGNANT RABBITS

\begin{tabular}{|c|c|c|c|}
\hline & $\begin{array}{c}\text { Uterine } \\
\text { fluid/ } \\
\text { hom }(\mu l)\end{array}$ & $\begin{array}{c}\text { Total protein/ } \\
\text { horn }(\mathrm{mg})\end{array}$ & $\begin{array}{l}\text { Protein conc. } \\
\text { of uterine fluid } \\
(\mathrm{mg} / \mathrm{ml})\end{array}$ \\
\hline $\begin{array}{l}\text { Pregnant } \\
3 \text { days p.c.* } \\
5 \text { days p.c. } \\
6 \text { days p.c. } \\
7 \text { days p.c. Occupied } \\
8 \text { days p.c. Occupied } \\
\text { Empty }{ }^{\dagger}\end{array}$ & $\begin{array}{r}16 \\
16 \\
67 \\
230 \\
53 \\
173 \\
23\end{array}$ & $\begin{array}{r}1 \cdot 67 \\
2 \cdot 80 \\
4 \cdot 42 \\
5 \cdot 96 \\
7 \cdot 56 \\
10 \cdot 61 \\
1 \cdot 88\end{array}$ & $\begin{array}{r}104 \cdot 5 \\
175 \cdot 3 \\
66 \cdot 0 \\
25 \cdot 9 \\
142 \cdot 6 \\
61 \cdot 3 \\
81 \cdot 9\end{array}$ \\
\hline Lactating, 6 days p.p. & 83 & 0.231 & $2 \cdot 78$ \\
\hline $\begin{array}{l}\text { Pseudopregnant } \\
3 \text { days } p . c . \\
4 \text { days p.c. } \\
5 \text { days p.c. } \\
6 \text { days } p . c . \\
10 \text { days } p . c .\end{array}$ & $\begin{array}{l}24 \\
26 \\
45 \\
28 \\
16\end{array}$ & $\begin{array}{l}0.918 \\
2.2 \\
5.92 \\
1.55 \\
0.744\end{array}$ & $\begin{array}{r}38.3 \\
84.6 \\
131.6 \\
55.2 \\
46.5\end{array}$ \\
\hline
\end{tabular}

* post coitum.

† Values from single horns; other entries in columns 2 and 3 are means of values from two to five horns.

$\ddagger$ post partum.

\section{Changes in volume and protein concentration}

Tables 1 and 2 show that the uterine lumen of non-pregnant rabbits has $18.5 \mu \mathrm{l}$ of fluid and $14.5 \mathrm{mg}$ of protein per $\mathrm{ml}$ of this fluid. Lactating and non-pregnant rabbits have similar amounts of protein per horn $(0.231$ and $0.268 \mathrm{mg}$, respectively), but the former have a greater volume of fluid $(83 \mu \mathrm{l})$ of lower protein concentration $(2.78 \mathrm{mg} / \mathrm{ml})$. Volume and protein concentration change differently with pregnancy (Table 2 ). The volume remains at about non-pregnant levels from 3 to 5 days p.c., but protein increases to ten times at 5 days p.c., raising the concentration above plasma level to $175 \cdot 3$ $\mathrm{mg} / \mathrm{ml}$. At 6 days p.c., the volume has gone up to four times the value in non-pregnant rabbits, but the amount of protein has only increased $1 \frac{1}{2}$ times so that there is a decrease in concentration. The volume increases further to $3 \frac{1}{2}$ times at 7 days p.c., if the horn contains blastocysts, but remains the same 
or decreases if the horn is empty. With pseudopregnancy, fluid volume increases to a peak at 5 days p.c. and then declines. Protein concentration reaches a peak value at 5 days p.c. $(131.6 \mathrm{mg} / \mathrm{ml})$, which is above the plasma level.

Rupture of blastocysts is a potential source of error in estimates from pregnant rabbits. $\mathrm{Up}$ to 7 days p.c., blastocysts recovered from the rinse were always found to be intact. At 7 days p.c., fluid spontaneously entered the tube inserted into occupied horns. The anterior end of the horn yielded enough fluid to suggest that there was about $230 \mu \mathrm{l}$ (Table 2) in the entire horn. At 8 days p.c., one could be more certain that rinses were not contaminated, since single blastocysts at this stage contain from 0.4 to $0.6 \mathrm{ml}$ fluid (Lutwak-Mann et al. 1960 ), which is two to three times the uterine fluid volume. Also, in unilaterally pregnant rabbits at 7 and 8 days p.c., while no fluid could be aspirated from empty horns, fluid from occupied horns entered the polyethylene tube even before rinsing. Prompt clotting on withdrawal of blastocyst fluid at 8 days p.c. (Lutwak-Mann, 1954) provides further evidence. Some rinses at 8 days p.c. were observed to clot and were discarded. Table 2 includes only data from rinses which did not clot and were presumably free of blastocyst fluid.

\section{DISGUSSION}

Use of the method described here has revealed major changes in uterine fluid volume. Large fluctuations in volume have been recorded in the rat (Warren, 1938) but, in the rabbit, only fluid from ligated uteri has been measured so far (Markee, Wells \& Hinsey, 1936; Shih, Kennedy \& Huggins, 1940; Gregoire, Gongsakdi \& Rakoff, 1961; Stevens, Hafs \& Kirton, 1964). Fluid from ligated uteri is abnormal in volume, electrolytes, nitrogen, carbohydrate and protein fractions (Ringler, 1961; Heap, 1962; Krishnan \& Daniel, 1967). The single observation of fluid at ovulation in rabbit uteri (Lutwak-Mann, 1962) appears to be related to animals confined in a warm dark place.

Volume changes of uterine fluid, with or without changes in concentration, suggest alterations in transmural permeability of the uterus. There are evidences for differences in permeability during early gestation (Lutwak-Mann et al., 1960; Orsini \& McLaren, 1967; Marley \& Robson, 1967). Such changes would be critical to the development of the rabbit blastocyst, which increases $10^{4}$-fold in volume between 4 and 8 days p.c. (Daniel, 1964). Therefore, measurement of volume is important, even if luminal concentration of substances can be determined from aspirated samples.

Heap \& Lamming (1962) found increased amounts of potassium, phosphorus, nitrogen and carbohydrate in uterine washes after progesterone treatment, but could not detect changes in the volume of luminal fluid. Comparisons based only on amounts per horn can be very misleading. For example, the uterine lumen of non-pregnant and lactating rabbits have the same amounts of protein but quite different protein concentrations (Table 2). Present estimates of mg protein per horn agree well with those of Heap (1962) and are somewhat lower than Schwick's (1965) values for 3- to 7-day-pregnant rabbits.

Both volume and concentration are essential for accurate comparisons 
between species and, within species, between stages of reproduction or different hormone treatments. Constituents of uterine fluid have been shown to be influenced by the hormonal and reproductive status of the uterus in the human (Hall, Sedlis, Chabon \& Stone, 1965; Kar, Engineer, Goel, Kamboj, Dasgupta \& Chowdhury, 1968) and several other species (Heap \& Lamming, 1962; Krishnan \& Daniel, 1967; Beier, 1968; Daniel, 1968). Estimates of volume and protein concentration obtained here suggest that these parameters may be sensitive indicators of the state of the uterus and therefore important diagnostic aids.

\section{AGKNOWLEDGMENTS}

I wish to thank Dr B. G. Böving for his comments and Mrs Floy L. Crutchfield for technical assistance. This study was supported by the Lalor Foundation.

\section{REFERENCES}

BEIER, H. M. (1968) Uteroglobin: a hormone-sensitive endometrial protein involved in blastocyst development. Biochim. biophys. Acta, 160, 289.

Daniel, J. C., JR (1964) Early growth of rabbit trophoblast. Am. Nat. 48, 85.

DANIEL, J. C., JR (1968) Comparison of electrophoretic patterns of uterine fluid from rabbits and mammals having delayed implantation. Comp. Biochem. Physiol. 24, 297.

FAHEY, J. L. \& MaKELVEY, E. M. (1965) Quantitative determination of serum immunoglobulins in antibody-agar plates. F. Immun, 94, 84.

Gornall, A. G., Bardawill, C. J. \& David, M. M. (1949) Determination of serum proteins by means of the biuret reaction. 7 . biol. Chem. 177, 751 .

GregorRe, A. T., Gongsakdi, D. \& RakofF, A. E. (1961) The free amino acid content of the female rabbit genital tract. Fert. Steril. 12, 322.

Hall, H. H., Sedirs, A., Ghabon, I. \& Stone, M. L. (1965) Effect of intrauterine stainless steel ring on endometrial structure and function. Am. F. Obstet. Gynec. 93, 1031.

Handbook of Ghemistry and Physics (1968) Ed. R. G. Weast. 49th edn., p. D174. The Ghemical Rubber Co., Ohio.

HEAP, R. B. (1962) Some chemical constituents of uterine washings: a method of analysis with results from various species. 7. Endocr. 24, 367.

Heap, R. B. \& Lamming, G. E. (1962) The influence of ovarian hormones on some chemical constituents of the uterine washing of the rat and rabbit. F. Endocr. 25, 57.

Kar, A. B., Engineer, A. D., Goel, R., Kamboj, V. P., Dasgupta, P. R. \& Ghowdhury, S. R. (1968) Effect of an intrauterine contraceptive device on biochemical composition of uterine fluid. Am. 7. Obstet. Gynec. 101, 966.

Krishnan, R. S. \& Dantel, J. G., JR (1967) 'Blastokinin': inducer and regulator of blastocyst development in the rabbit uterus. Science, N.Y. 158, 490.

Kulangara, A. C. (1960) The macromolecular environment of the rabbit embryo before and during implantation. Yb. Carnegie Insin Wash. 59, 361.

Lutwak-Mann, C. (1954) Some properties of the rabbit blastocyst. F. Embryol. exp. Morph. 2, 1.

LutWAK-MANN, G. (1962) Some properties of uterine and cervical fluid in the rabbit. Biochim. biophys. Acta, 58, 637.

Lutwak-Mann, G., Boursnell, J. G. \& Bennett, J. P. (1960) Blastocyst-uterine relationships: uptake of radioactive ions by the early rabbit embryo and its environment. F. Reprod. Fert. 1, 169.

Markee, J. E., Wells, W. M. \& Hinsex, J. G. (1936) Studies on uterine growth. III. A local factor in the rabbit uterus. Anat. Rec. 64, 221.

Marley, P. B. \& Robson, J. M. (1967) The passage of ${ }^{22} \mathrm{Na}$ into the uterine lumen of the rat. $\mathcal{F}$. Physiol., Lond. 189, 67P.

Orsini, M. W. \& MaLaren, A. (1967) Loss of the zona pellucida in mice and the effect of tubal ligation and ovariectomy. F. Reprod. Fert. 13, 485.

RINGLER, I. (1961) The composition of rat uterine luminal fluid. Endocrinology, 68, 281.

ScHwick, H. G. (1965) Chemisch-Entwicklungsphysiologische beziehungen von Uterus zu Blastocyste des Kaninchens Oryctolagus cuniculus. Arch. EntwMech. Org. 156, 283. 
Shit, H. E., Kennedy, J. \& Huggins, C. (1940) Chemical composition of uterine secretions. Am. 7 . Physiol. 130, 287.

Stevens, K. R., Hafs, H. D. \& Kirton, K. T. (1964) Volume, pH and protein content of fluids from ligated uteri of oestrous rabbits. F. Reprod. Fert. 7, 331.

Turt, P. H. \& Böving, B. G. (1970) The forces involved in water uptake by the rabbit blastocyst. F. exp. Zool. 174, 165.

Warren, M. R. (1938) Observations on the uterine fluid of the rat. Am. F. Physiol. 122, 602.

ZACHARIAE, F. (1958) Autoradiographic $\left({ }^{35} \mathrm{~S}\right)$ and histochemical studies of sulphomucopolysaccharides in the rabbit uterus, oviducts and vagina. Acta endocr., Copenh. 29, 118. 